\title{
Effects of sulfuric acid and nitrogen deposition on mineral nutrition of Picea abies (L.) Karst.
}

\author{
B.U. Schneider, M. Kaupenjohann and W. Zech
}

Lehrstuhl für Bodenkunde und Bodengeographie der Universität Bayreuth, Postfach 101251 , D-8580 Bayreuth, F.R.G.

\section{Introduction}

Since $1980, \mathrm{Mg}$ deficiency in spruce ecosystems of the NE-Bavarian mountains has caused needle yellowing and subsequent dieback of trees growing on soils low in base saturation (Zech and Popp, 1983). At an altitude above $700 \mathrm{~m}, \mathrm{Mg}$ content of current year needles hardly exceeds $0.03 \%$ of dry weight. $\mathrm{N}$ needle contents range between 1.3 and $1.6 \%$, which is a sufficient supply. $\mathrm{Ca}, \mathrm{K}$ and $\mathrm{Zn}$ concentrations are low, whereas $S$ concentrations of more than $0.2 \%$ of dry weight are extremely high, corresponding to the high $\mathrm{SO}_{2}$-content of the air in this region (Zech et al., 1983).

The proton input of about 1.5-4.5 $\mathrm{kmol} \cdot \mathrm{ha} \cdot \mathrm{a}^{-1}$ (Kaupenjohann, 1989), measured on experimental sites in the Fichtelgebirge, and low fogwater $\mathrm{pH}$ (Trautner, 1989) of 2.2 indicate a high acid stress for forest ecosystems. In fogwater, $\mathrm{NH}_{4}$ concentrations may also be extremely high (up to 19.5 meq.1-1; Trautner, 1988). Total $\mathrm{N}$ deposition of $20-30 \mathrm{~kg} \cdot \mathrm{ha} \cdot \mathrm{a}^{-1}$ exceeds the $\mathrm{N}$ demand of trees and high amounts of nitrate are washed out of the soils (Hantschel, 1987).

To study the effects of air pollutants on spruce ecosystems, saplings have been sprayed with artificial acid rain, structured soil samples have been extracted with sulfuric acid, and the effects of high $\mathrm{NH}_{4}$ inputs on tree nutrition have been measured close to a chicken farm.

\section{Materials and Methods}

\section{Sulfuric acid treatment of spruce sapling}

Seedlings, $3 \mathrm{yr}$ old, growing in a nutrient solution were sprayed 3 times a day with $62.5 \mathrm{ml}$ of $\mathrm{H}_{2} \mathrm{SO}_{4}(\mathrm{pH}$ 2.4) or deionized water (pH 5.6) during a 10 day period (Kaupenjohann et al., 1988).

Sulfuric acid treatment of naturally structured soil samples

Naturally structured soil samples $\left(100 \mathrm{~cm}^{3}\right)$ were extracted under saturated conditions using $\mathrm{H}_{2} \mathrm{SO}_{4}$ concentrations corresponding to calculated (Ulrich, 1983) $\mathrm{H}^{+-}$-buffering of canopies in spruce ecosystems in the Fichtelgebirge (Kaupenjohann and Hantschel, 1987; Kaupenjohann, 1989). 
Table I. Total acidity in the nutrient solution, cation leaching from the canopy and $\mathrm{K}, \mathrm{Ca}$ and $\mathrm{Mg}$ needle contents in non-stressed $(A)$ and acidically stressed (B) $P$. abies saplings.

\begin{tabular}{|c|c|c|c|c|c|c|c|c|}
\hline \multirow[t]{2}{*}{ Treatment } & $\begin{array}{l}\text { Total acidity } \\
\text { (nutrient sol.) }\end{array}$ & \multicolumn{3}{|c|}{ Needle leaching } & \multicolumn{3}{|c|}{ Needle conc. } & \multirow{2}{*}{$\begin{array}{l}\text { Needle Mg } \\
\text { content } \\
(\mu e q / \text { tree })\end{array}$} \\
\hline & $\begin{array}{r}\text { (nutrient sol.) } \\
(\mu \epsilon\end{array}$ & $\bar{K}$ & $\mathrm{Ca}$ & $\overline{M g}$ & $\bar{K}$ & $\mathrm{Ca}$ & $M g$ & \\
\hline $\begin{array}{l}A \\
B \\
B-A\end{array}$ & $\begin{array}{r}440 \\
500 \\
60\end{array}$ & $\begin{array}{l}25 \\
55 \\
30\end{array}$ & $\begin{array}{l}\overline{20} \\
20\end{array}$ & $\begin{array}{l}\overline{65} \\
65\end{array}$ & $\begin{array}{l}6.8 \\
6.1\end{array}$ & $\begin{array}{l}11.2 \\
10.3\end{array}$ & $\begin{array}{l}1.5 \\
0.9\end{array}$ & $\begin{array}{l}285 \\
240 \\
-45\end{array}$ \\
\hline
\end{tabular}

Effects of high $\mathrm{N}$-inputs near a chicken farm on nutrient status and vitality of Pinus sylvestris (L.)

Vitality, nutrient supply of $P$. sylvestris, chemical constitution of the soil solution and $\mathrm{NH}_{4}$ concentrations of the air were determined on the experimental site at various distances $(50-600 \mathrm{~m})$ and directions from a chicken farm (Kaupenjohann et al., 1989).

\section{Results and Discussion}

From saplings treated with sulfuric acid (B) $30 \mu$ eq more $\mathrm{K}$ had been leached than from control trees sprayed with deionized water (A). No $\mathrm{Ca}$ and $\mathrm{Mg}$ leaching could be measured in the water treatment (A). Sulfuric acid, however, caused a release of $20 \mu \mathrm{eq}$ of $\mathrm{Ca}$ and $65 \mu \mathrm{eq}$ of $\mathrm{Mg}$ per tree. $\mathrm{K}$ and $\mathrm{Ca}$ needle contents did not differ between both treatments, however, $\mathrm{Mg}$ concentrations in needles of stressed trees decreased significantly by about $45 \mu$ eq compared to trees sprayed with water (Table I). In the nutrient solution, we measured an increase of total acidity of about $60 \mu \mathrm{eq}$ per tree as a result of the acid treatment (Kaupenjohann et al., 1988).

These findings confirm Ulrich's hypothesis (Ulrich, 1983) that cation leaching from a tree's canopy leads to an additional acidification of the rhizosphere resulting from enhanced cation uptake.
The acidification of the root microenvironment affected root nutrient uptake (Schneider et al., 1989): fine root $\mathrm{Ca}$ content of acidically treated saplings (B) was significantly lower $(26 \%)$ compared to those sprayed with deionized water (Table II). The decrease in root $\mathrm{Mg}$ was less pronounced due to the high mobility of this element within the plant (Rademacher, 1986). The K contents of fine roots were the same in the two treatments (Table II).

To test what effects this specific proton input to the rhizosphere has on soil chemistry, cation release from undisturbed soil samples was investigated (Kaupenjohann and Hantschel, 1987) using sulfuric acid of $\mathrm{pH}$ 's corresponding to the average proton buffering of the canopy of various spruce stands of the Fichtelgebirge. The equivalent fraction of $\mathrm{Mg}(\% \mathrm{Mg}$ of $\Sigma \mathrm{K}, \mathrm{Ca}, \mathrm{Mg}$, Al) in the solution of those extracts significantly relates to $\mathrm{Mg}$ needle contents (Fig.

Table II. $\mathrm{Ca}, \mathrm{Mg}$ and $\mathrm{K}$ concentrations in living fine roots $(\mu \mathrm{g} / \mathrm{g} \mathrm{dw})$ of spruce saplings treated with deionized water (A) and sulfuric acid (B) (Schneider et al., 1989).

\begin{tabular}{llllll}
\hline \multirow{2}{*}{ Element } & \multicolumn{2}{l}{ Treatment $A$} & & \multicolumn{2}{c}{ Treatment $B$} \\
\cline { 2 - 3 } \cline { 5 - 6 } & $\bar{x}$ & $S E$ & & $\bar{x}$ & $S E$ \\
\hline $\mathrm{Ca}^{\mathrm{a}}$ & 5102 & $(249)$ & & 3778 & $(415)$ \\
$\mathrm{Mg}$ & 2271 & $(144)$ & & 2135 & $(106)$ \\
$\mathrm{K}$ & 6399 & $(206)$ & & 5629 & $(465)$ \\
\hline
\end{tabular}

asignificant differences $(P<0.01)$. 


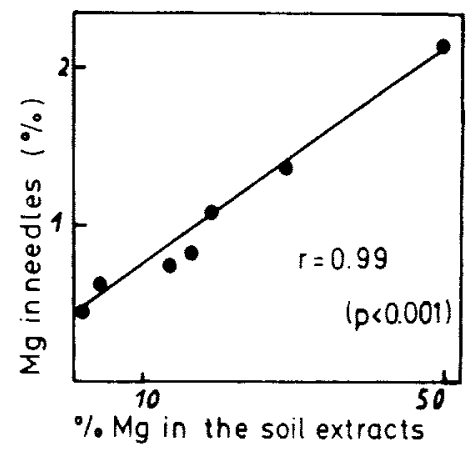

Fig. 1. Mg needle content of recent spruce needles (1985/1986) at various sites in NE-Bavaria as a function of $\mathrm{Mg}$ content in sulfuric acid extracts (equivalent fraction of $\Sigma \mathrm{K}, \mathrm{Ca}, \mathrm{Mg}, \mathrm{Al}$ ) of naturally structured soil samples (see text; Kaupenjohann, 1989).

1), indicating that $\mathrm{Mg}$ availability seems to be mainly a function of acid deposition and $\mathrm{Mg}$ supply of the soil (Kaupenjohann, 1989).

It is interesting to note that an increase of the acid load of the same soil (Fig. 2) caused a higher release of both $\mathrm{Mg}$ and $\mathrm{Ca}$ into the soil solution (Kaupenjohann and Hantschel, 1987). From field studies, we know that the proton input into old stands can exceed that of young ones by a factor of $2-3$, because of the higher canopy filtering capacity (Kaupenjohann, 1989). Actual $\mathrm{Ca}$ and $\mathrm{Mg}$ availability in old spruce stands, therefore, should increase under the same soil conditions (Kaupenjohann, 1989).

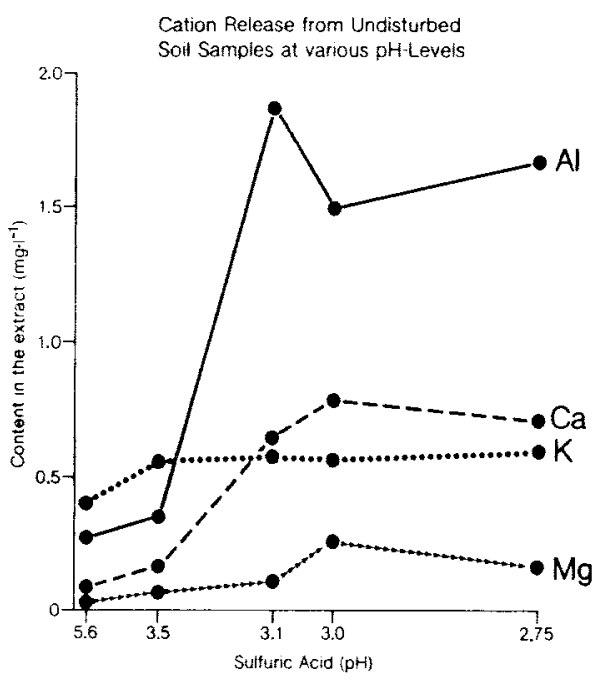

Fig. 2. Cation release from naturally structured soil samples of a declining spruce stand in the Fichtelgebirge at a decreasing $\mathrm{pH}\left(\mathrm{H}_{2} \mathrm{SO}_{4}\right)$ of the extraction solution (Kaupenjohann and Hantschel, 1987).

Indeed, we measured a significant increase of fine root $\mathrm{Mg}$ in an old stand compared to a young stand at the same site (Table III). The $\mathrm{Ca}$ content in living fine roots was, however, significantly lower in old than in young spruce. The Ca/Al ratios of roots from old and young trees did not differ significantly (Schneider et al., 1989).

We therefore think that proton release from fine roots may restrict $\mathrm{Ca}$ uptake more directly than does $\mathrm{Al}$ in the soil solu-

Table III. Contents of $\mathrm{Ca}$ and $\mathrm{Mg}$ and $\mathrm{Ca} / \mathrm{Al}$ molar ratio in fine roots of young and old declining spruce (P. abies (L.) Karst.) (Schneider et al., 1989).

\begin{tabular}{|c|c|c|c|c|c|c|c|c|}
\hline \multirow[t]{2}{*}{ Stand } & \multirow[t]{2}{*}{$n$} & \multirow{2}{*}{$\begin{array}{l}H^{+} \text {-input } \\
(\mathrm{kmol})\end{array}$} & \multicolumn{6}{|c|}{ Element $\left(\mu \mathrm{mol} \cdot \mathrm{g}^{-1}\right)$} \\
\hline & & & $C a^{a}$ & $S E$ & $M g^{a}$ & $S E$ & $\mathrm{Ca} / \mathrm{A}$ & $S E$ \\
\hline Young & 5 & $1.5-2$ & 67.88 & 58 & 14.85 & 34 & 0.26 & 44 \\
\hline Old & 20 & $3-4.5$ & 57.21 & 8 & 19.99 & 17 & 0.27 & 6 \\
\hline
\end{tabular}

a Significant difference; $P<0.05$.

b Not significant. 
Table IV. Nutrient contents in current year needles of healthy (A) and declining (B) P. sylvestris (L.) (Kaupenjohann et al., 1989).

\begin{tabular}{llllll}
\hline Stand & \multicolumn{5}{l}{ Needle content $\left(\mathrm{mg} \cdot g^{-1} \mathrm{dw}\right)$} \\
\cline { 2 - 6 } & $\mathrm{N}$ & $P$ & $K$ & $\mathrm{Ca}$ & $M g^{\mathrm{a}}$ \\
\hline A & 27 & 1.6 & 6.1 & 3.4 & 0.92 \\
$\mathrm{~B}$ & 24 & 1.4 & 6.7 & 3.5 & 0.66 \\
\hline
\end{tabular}

a Significant difference; $P<0.01$.

tion. $\mathrm{Mg}$ uptake does not seem to be restricted by an efflux of protons from roots and average $\mathrm{Al}$ concentrations in the soil solution of about 2-8 mg.t-1 (Hantschel, 1987).

The results can describe a causal relationship between acid deposition, cation leaching, acidification of the tree's rhizosphere, changes in soil chemistry and plant nutrition. In addition to the proton deposition, $N$ inputs have to be taken into account when investigating influences on nutritional imbalances in forest ecosystems.

We therefore studied the effects of high $\mathrm{NH}_{4}$ input on $P$. sylvestris (L.) close to a chicken farm (Kaupenjohann et al., 1989). Needle analysis showed high $\mathrm{N}$ concentrations (Table IV) in both a healthy stand (A) growing $50 \mathrm{~m}$ to the west of a farm and a leeward localized declining stand (150 $\mathrm{m}$ to the east). P, K and Ca needle contents also differed between the stands (Table IV). Mg concentrations in needles

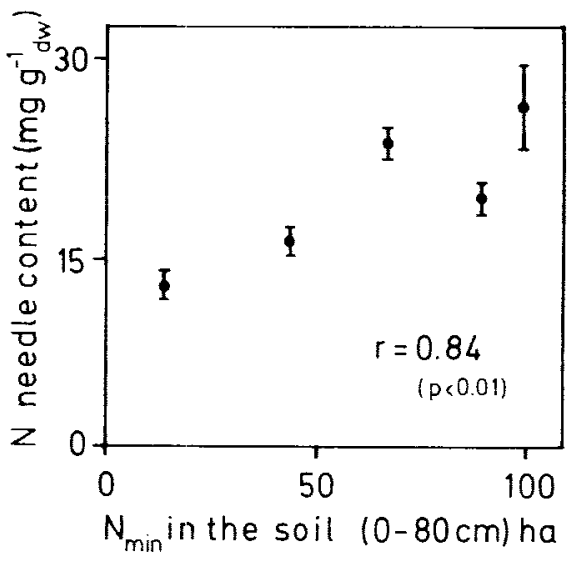

Fig. 3. $N$ needle content as a function of $N$ supply in the soil on experimental plots at various distances from a chicken farm (Kaupenjohann et al., 1989).

of damaged trees $(\mathrm{B})$, however, were significantly lower ( $30 \%$; Table IV) than in healthy trees $(\mathrm{A})$, although soil $\mathrm{Mg}$ was even higher in the damaged stand (Table $V)$. The amount of plant-available $N$ in the soil was similar at both plots, which correlates well with the $\mathrm{N}$ supply of the trees (Fig. 3) (Kaupenjohann et al., 1989).

Microclimatic observations showed that, in the healthy stand (A), nitrogen was mainly deposited underneath the canopy directly on the soil, whereas at the declining stand ( $\mathrm{B}$ ) $\mathrm{N}$-inputs were impacted on the canopy (Kaupenjohann et al., 1989). It may therefore be assumed that trees are able to metabolize the increased supply of

Table V. pH, $\mathrm{N}_{\min }$ and elemental content in the soil water extracts of healthy $(A)$ and damaged $(B)$ P. sylvestris (L.).

\begin{tabular}{|c|c|c|c|c|c|c|c|}
\hline \multirow[t]{2}{*}{ Stand } & \multirow[t]{2}{*}{$p H$} & \multicolumn{2}{|c|}{$N_{\min }\left(k g \cdot h a^{-1}\right)^{a}$} & \multicolumn{4}{|c|}{ Element $\left(m g \cdot r^{-1}\right)^{a}$} \\
\hline & & $\mathrm{NH}_{4}$ & $\mathrm{NO}_{3}$ & $M g$ & $K$ & $\mathrm{Ca}$ & $A l$ \\
\hline $\begin{array}{l}A \\
B\end{array}$ & $\begin{array}{l}3.91 \\
3.99\end{array}$ & $\begin{array}{l}36.6 \\
35.7\end{array}$ & $\begin{array}{l}5.2 \\
3.5\end{array}$ & $\begin{array}{l}0.19 \\
0.29\end{array}$ & $\begin{array}{r}13.6 \\
8.4\end{array}$ & $\begin{array}{l}27 \\
27\end{array}$ & $\begin{array}{l}17 \\
10\end{array}$ \\
\hline
\end{tabular}

a Soil depth: $0-20 \mathrm{~cm}$. 
soil $N$ without developing imbalanced nutrient relations within the plant. In contrast, a direct attack of $\mathrm{NH}_{4}$ on a tree's canopy may decrease nutrient supply due to leaching. Laboratory experiments by Hogrebe and Mengel (in preparation) support this hypothesis. In addition, $\mathrm{NH}_{4} / \mathrm{NH}_{3}^{-}$ deposition may have toxic effects on the plant tissue (Ewert, 1978).

\section{Conclusion}

Acid deposition based on high $\mathrm{SO}_{2}^{-}$inputs in the NE-Bavarian Mountains cause an imbalance in the nutrient supply of soils and plants, leading to cation leaching from damaged trees and subsequent acidification of the rhizosphere due to enhanced cation uptake by roots. $\mathrm{Mg}$ seems to be especially affected by this process explaining the extensive symptoms of needle yellowing and dieback of spruce stands in this region. Furthermore, proton load, particularly of the canopy, decreases $\mathrm{Ca}$ uptake into roots. There is no indication of an imbalancing effect of high $\mathrm{N}$ supply on nutrient relations within the plant. Ammonium deposition may, however, cause $\mathrm{Mg}$ leaching as sulfuric acid does, and thus induce $\mathrm{Mg}$ deficiency.

\section{References}

Ewert E. (1978) Vegetationsschäden in der umgebung landwirtschaftlicher tierproduktionsanlagen. Luft Kältetech. 4, 218-220

Hantschel R. (1987) Wasser-und elementbilanz von geschädigten, gedüngten fichtenökosyste- men im Fichtelgebirge unter berücksichtigung von physikalischer und chemischer bodenheterogenität. Bayreuther Bodenkund. Ber., 5, 3 (ISSN 0931-6442) 1-219

Kaupenjohann M. \& Hantschel R. (1987) Die kurzfristige $\mathrm{pH}$-pufferung von gestörten und ungestörten waldbodenproben. $Z$. Pflanzenernaehr. Bodenkd. 150, 156-160

Kaupenjohann M., Döhler H. \& Bauer M. (1989) Effects of $\mathrm{N}$-immissions on nutrient status and vitality of Pinus sylvestris (L.) near a hen house. Plant Soil 133, 279-288

Kaupenjohann M., Schneider B.U., Hantschel R., Zech W. \& Horn R. (1988) Sulfuric acid rain treatment of Picea abies (L.) (Karst.): effects on nutrient solution and throughfall chemistry as well as on spruce nutrition. $Z$. Pflanzenernaehr. Bodenkd. 151, 123-126

Rademacher P. (1986) Morphologische und physiologische eigenschaften von fichten (Picea abies (L.) Karst), tannen (Abies alba Mill), kiefern (Pinus sylvestris L.) und buchen (Fagus sylvatica L.) gesunder und erkrankter waldstandorte. Dissertation, Fachbereich Biologie, Universität Hamburg, F.R.G.

Schneider B.U., Meyer J., Schulze E.D. \& Zech W. (1989) Biomass, elemental and carbohydrate contents of roots from healthy and declining Picea abies (L.) Karst. stands. In: Ecological Studies 77 (Schulze E.D., Lange O. \& Oren K., eds.), Springer-Verlag, Berlin (in press)

Trautner F. (1989) Collection and properties of fogwater. In: Ecological Studies. (Schultz E.D., ed.), Springer-Verlag, Berlin (in press)

Ulrich B. (1983) Interactions of forest canopies with atmospheric constituents: $\mathrm{SO}_{2}$, alkali and earth alkali cations and chloride. In: Effects of Accumulation of Air Pollutants in Forest Ecosystems. (Ulrich B. \& Pankrath J., eds.), Reidel Publ. Co., Dordrecht, pp. 33-45

Zech W. \& Popp E. (1983) Magnesiummangel einer der gründe für das fichten und tannensterben in NO-Bayern. Forstwiss. Cbl. 102, 50-55

Zech W., Suttner T. \& Popp E. (1983) Elemental analysis and physiological responses of forest trees in $\mathrm{SO}_{2}$-polluted areas of NE-Bavaria. Water Air Soil Pollut. 25, 175-183 